\title{
Local geoid determination using a generalized regression neural network and interpolation methods: A case study in Kars, Turkey
}

\author{
Alper $\mathrm{AKAR}^{1 *}(\mathbb{D}$, Berkant Konakoğlu² \\ $1^{*}$ Erzincan Binali Yıldırım Üniversitesi, Meslek Yüksek Okulu, Harita ve Kadastro Programı, Erzincan, \\ Türkiye \\ ${ }^{2}$ Amasya Üniversitesi, Teknik Bilimler Meslek Yüksek Okulu, Harita ve Kadastro Programı, Amasya, \\ Türkiye
}

Geliş / Received: 04/12/2020, Kabul / Accepted: 27/12/2020

\begin{abstract}
This study aimed to determine the most suitable local geoid model based on $641 \mathrm{GNSS} /$ leveling points within the borders of Kars Province in eastern Turkey using the generalized regression neural network (GRNN), weighted average (WA), multiquadric (MQ), inverse multiquadric (IMQ) function, and local polynomial (LP) method. Among these methods used in local geoid determination, the studies conducted with the GRNN method are very limited in the literature. To test the performance of the model, 169 GNSS/leveling points were selected as test data. When selecting reference points and test points, care was taken to distribute these points homogeneously within the study area. The criteria of root mean square error (RMSE), mean absolute error (MAE), and coefficient of determination $\left(\mathrm{R}^{2}\right)$ were used to assess the accuracy and error rates of the results achieved using the different methods. According the results of analysis, GRNN method yielded better results than other interpolation methods. These results have showed that GRNN method can be taken into account in modeling various geodesy problems.

Keywords: Generalized regression neural network (GRNN), geoid undulation, GNSS/leveling, interpolation methods
\end{abstract}

\section{Genelleştirilmiş regresyon sinir ağı ve bazı enterpolasyon yöntemlerini kullanarak yerel jeoid}

\author{
belirleme: Kars, Türkiye'de bir vaka çalışması
}

\section{Öz}

Bu çalışmada Türkiye'nin doğusunda yer alan Kars il sınırları içerisinde bulunan 641 tane GNSS/nivelman noktasına dayalı olarak, genelleştirilmiş regresyon yapay sinir ağı (GRNN), ağırlıklı ortalama (WA), multikuadrik (MQ) fonksiyonu, ters multikuadrik (IMQ) fonksiyonu ve yerel polinom (LP) yöntemleri kullanılarak en uygun yerel jeoid modelinin belirlenmesi amaçlanmıştır. Lokal jeoid belirlemede kullanılan bu yöntemler arasından GRNN yöntemi ile yapılan çalışmaların sayısı literatürde oldukça sınırlıdır. Modelin performansını test etmek için 169 tane GNSS/nivelman noktası test verisi olarak seçilmiştir. Referans noktaları ve test noktaları seçilirken, bu noktaların çalışma alanı içerisinde homojen olarak dağılmasına özen gösterilmiştir. Farklı yöntemlerden elde edilen sonuçların doğruluğunu ve hata oranlarını öğrenmek için, karesel ortalama hata (RMSE), ortalama mutlak hata (MAE) ve belirlilik katsayısı $\left(\mathrm{R}^{2}\right)$ kriterleri kullanılmıştır. Analiz sonuçlarına göre GRNN metodu, diğer interpolasyon yöntemlerine göre daha iyi sonuçlar vermiştir. Bu sonuçlar, GRNN metodunun çeşitli jeodezi problemlerinin modellenmesinde dikkate alınabileceğini göstermiştir..

Anahtar Kelimeler: Genelleştirilmiş regresyon sinir ağı, jeoid ondülasyonu, GNSS/nivelman, enterpolasyon yöntemleri 


\section{Introduction}

Despite scientific and technological advances, geometric leveling is still used as a more practical way of determining orthometric height $(\mathrm{H})$. Currently, ellipsoidal heights can be determined with high accuracy using global navigation satellite system (GNSS) techniques. Ellipsoidal height is a geometric height, and since it has no physical meaning, orthometric heights are used in engineering studies (Featherstone, 1998). If geoid undulation values with a specific accuracy are known, they can be easily converted from the ellipsoidal heights obtained with GNSS to orthometric heights. A geoid can be defined as the equipotential surface of the gravitational field that coincides with the mean sea level. The geoid creates a reference surface for the physical heights of topographical points. This surface is formed under the gravitational force of the earth masses. Based on development methods and the data used, the different methods for geoid determination are generally divided into three types: gravimetric, astrogeodetic, and geometric (Becker, 2012). The geometric method relies on the relationship between the GNSS and orthometric heights to determine the geoid undulation and interpolates this value for an unknown point. In order to determine the local geoid, first, the points with both height values known are chosen as reference points. Creating and selecting the most appropriate and realistic model in geoid determination is extremely important for the practitioners using such models. In the literature to date, many interpolation and least square collocation methods have been used for the geometric modeling of local geoids (Zhan-ji and Yongqi, 1999; Yanalak and Baykal, 2001; Doganalp and Selvi, 2015; Doganalp, 2016;
Karaaslan, et al., 2016; Şişman and Elevli, 2018; Y1lmaz and Kuru, 2019; Y1lmaz, 2019).

The artificial neural network (ANN) method is used in solving engineering problems because of its non-linear structure and error tolerance. In geodetic studies, ANNs have been successfully used in geoid undulation modeling for different regions (Güllü et al., 2016; Kaloop, 2018; Fidanc1 and Abbak, 2019; Albayrak et al., 2020; Erol and Erol, 2020). For example, Seager et al. (1999) used a back propagation ANN to model the local geoid for an area of $2^{\circ} \times 2^{\circ}$. As a result of the study, they found that this method could be used as a tool in geoid undulation modeling. Kavzoglu and Saka (2005) designed an ANN to model geoid undulation for Istanbul using 190 GPS/leveling points. The results showed that the developed ANN model exhibited a lower error rate than the GPS/leveling data surface. Cakir and Yilmaz (2014) compared the geoid undulation estimates they carried out using the multilayer perceptron neural network (MLPNN) with polynomials and radial basis functions. According to the results of the study, they found that the MLPNN model gave more accurate results than the other methods tested.

The aim of this study was to design a suitable geoid model for Kars Province (Turkey). Six different methods were used in the study: generalized regression neural network (GRNN) from artificial neural network (ANN) models, weighted average (WA), multiquadric (MQ) and inverse multiquadric (IMQ) radial basis functions, and local polynomial (LP) function. During the implementation of the methods, 641 geodetic points with known ellipsoidal and orthometric heights were divided into "reference" and 
"test" data groups. The performances of the models were evaluated using root mean square error (RMSE), mean absolute error (MAE), and coefficient of determination $\left(\mathrm{R}^{2}\right)$. The results showed that according to the known geoid undulation values, the GRNN method gave better results for estimated values than the other interpolation methods.

\section{Material and Methods}

\subsection{Study area}

The province of Kars has the provinces of Ardahan to the north, Iğdır to the southeast, Ağr1 to the south and Erzurum to the west,
The orthometric and ellipsoidal height values of $641 \mathrm{C} 3$ order control points used within the scope of the study were provided by the the Erzincan XXIV Regional Directorate of Land Registry and Cadastre.

With attention given to their homogeneous distribution, 473 of the GNSS/leveling points were chosen as reference points and the remaining 169 as test points. The distributions of the reference and test points are shown in Figure 2. The ellipsoidal heights (h) of the points were determined in the ITRF96 datum at epoch 2005.0 using GNSS techniques and according to Turkey National Fundamental CPS Natwarl (TNECN)



Figure 1. Study area

with Armenia located to the East. Its total area is $10,139 \mathrm{~km}^{2}$ (Fig. 1).
The orthometric heights $(\mathrm{H})$ of the same points were calculated by referencing the Turkish National Vertical Control 
Network (TNVCN). The undulation (N) values of the geodetic points were obtained by subtracting the orthometric heights from the ellipsoidal heights of the points.

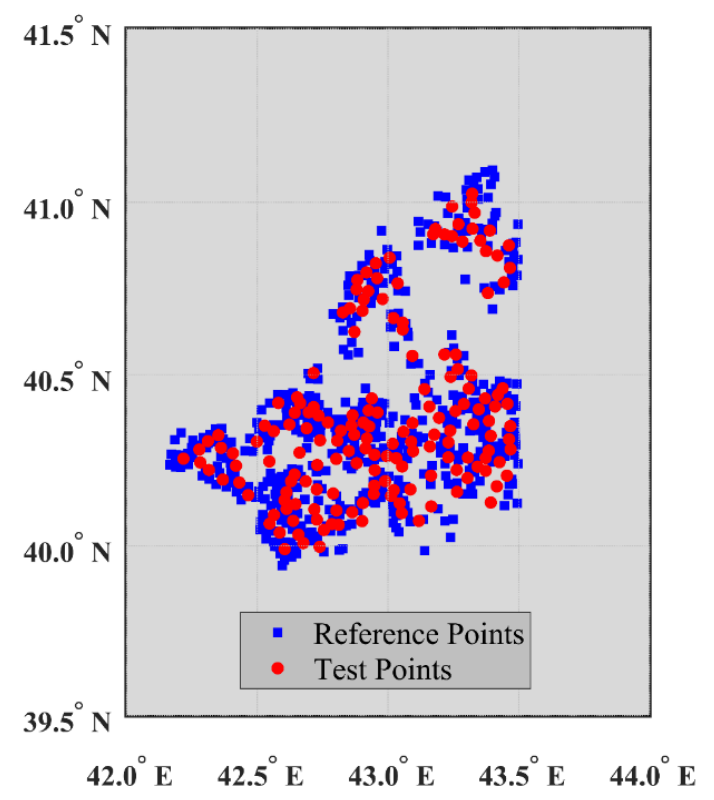

Figure 2. Distribution of reference and test points in the study area

Statistical properties (mean, maximum, minimum, and standard deviation) of the data (divided into reference and test data for the application) are shown in Table 1 . The values of all statistical properties were nearly the same for the reference and test datasets.
The GRNN consists of a total of four layers: an input layer, a pattern layer, a summation layer, and an output layer.

The general structure of the GRNN is given in Figure 3. In the GRNN method, developed by Donald Specht in 1991, the estimation function is created by using the input and output data.

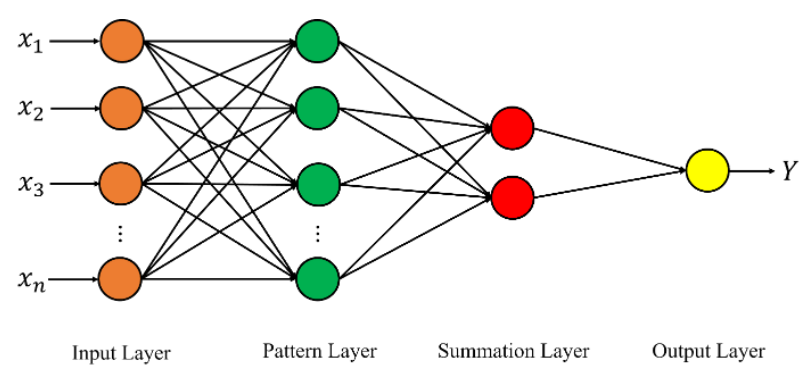

Figure 3. General GRNN structure

The GRNN is a radial basis feed-forward ANN model that does not require an iterative training procedure (Specht, 1991). Equation (1) shows the regression of the dependent variable $y$ with respect to the independent variable $x$, if the joint probability density function $f(x, y)$ is known.

$E[y \mid X]=\frac{\int_{-\infty}^{\infty} y f(X, y) d y}{\int_{-\infty}^{\infty} f(X, y) d y}$

Table 1. Statistical properties of reference and test data

\begin{tabular}{|c|c|c|c|c|c|}
\hline Data set & Coordinates & Mean & Maximum & Minimum & $\begin{array}{c}\text { Standard } \\
\text { Deviation }\end{array}$ \\
\hline \multirow{3}{*}{ Reference } & Latitude $\left(^{\circ}\right)$ & 40.382 & 41.093 & 39.942 & 0.269 \\
\hline & Longitude $\left({ }^{\circ}\right)$ & 42.943 & 43.497 & 42.167 & 0.338 \\
\hline & Undulation (m) & 25.761 & 35.614 & 23.372 & 1.027 \\
\hline \multirow{3}{*}{ Test } & Latitude $\left({ }^{\circ}\right)$ & 40.385 & 41.025 & 39.990 & 0.258 \\
\hline & Longitude $\left({ }^{\circ}\right)$ & 42.974 & 43.468 & 42.218 & 0.318 \\
\hline & Undulation (m) & 25.681 & 27.352 & 23.584 & 0.860 \\
\hline
\end{tabular}

\section{L.L. Generaiıed kegression Network (GRNN)}

veural When the density function is unknown, it must be usually be estimated a sample of observations of $x$ and $y$. The probability 
estimator $\hat{f}(x, y)$ is based on sapmle values $X^{i}$ and $Y^{i}$ of random variables $x$ and $y$.

$f(X, y)=\frac{1}{(2 \pi)^{(p+1) / 2} \sigma^{(p+1)}} \frac{1}{n} \times$

$\sum_{i=1}^{n} \exp \left[\frac{-\left(X-X^{i}\right)^{T}\left(X-X^{i}\right)}{2 \sigma^{2}}\right] \exp \left[\frac{-\left(Y-Y^{i}\right)^{2}}{2 \sigma^{2}}\right]$

In this equation, $p$ is the size of the vector $x, n$ is the number of data, and $\sigma$ shows the spread parameter, with $D_{i}^{2}$ being a scalar function:

$D_{i}^{2}=\left(X-X^{i}\right)^{T}\left(X-X^{i}\right)$

Equation (4) is obtained when the integrals in Equation (1) are solved:

$$
Y(X)=\frac{\sum_{i=1}^{n} Y^{\mathrm{i}} \exp \left(\frac{-D_{i}^{2}}{2 \sigma^{2}}\right)}{\sum_{i=1}^{n} \exp \left(\frac{-D_{i}^{2}}{2 \sigma^{2}}\right)}
$$

\subsection{Local Polynomial (LP) Interpolation}

In the LP method, calculation of interpolation values is performed by the weighted least squares (WLS) method. When calculating the height values of the interpolation points, the fulcrum points to be used are defined by a predetermined search ellipse. Using only the data within the scope of the search ellipse, all of the fulcrum points are weighted to generate the surface data and a local bivariate polynomial is generated. The uncertain coefficients in the polynomial produced are resolved according to the least squares method. The height values of the formed surface are calculated by the LP method (Solmaz, 2019). The degree of the most suitable polynomial to be used in the method is generally sought via experimental methods. The higher the degree of the polynomial, the closer the model and the data in the model to each other (Üstün, 2001). However, in practice, sensitivity losses in the estimated parameters as the degree of the model increases may cause increases in model error. Therefore, it would be appropriate to choose the degree of the polynomial as one degree lower in cases where the error in the model starts to rise (Ceylan et al., 2011). In the interpolation process using polynomials, it does not mean that increasing the degree of the polynomial will increase its sensitivity. Sudden decreases and increases in the created surface may cause altitude data changes that are not correct for the real surface (İnal et al., 2002). The local polynomials stated above are represented as first, second, and third degree polynomials.

If the function is expressed as first degree, it can be formulated as:

$F(X, Y)=a+b X+c Y$

where $a$ to $c$ are the three coefficients of transformation. If the function is expressed as second degree, it can be formulated as:

$F(X, Y)=a+b X+c Y+d X Y+e X^{2}+f Y^{2}$

where $a$ to $f$ are the six coefficients of transformation. If the function is expressed as third degree, it can be formulated as:

$F(X, Y)=a+b X+c Y+d X Y+e X^{2}+f Y^{2}+$ $g X^{2} Y+h X Y^{2}+i X^{3}+j Y^{3}$

where $a$ to $j$ are the ten coefficients of transformation. The basis of the WLS method used here is to give more weight to the fulcrum points close to the point to be interpolated and less weight to the points that are far from the point to be interpolated. The search ellipse in the weight function depends on the weight parameter and the distribution 
of the data. For the calculation of actual weights, first, the $T_{X X}, T_{X Y}, T_{Y X}$, and $T_{Y Y}$ parameters are calculated using Equation (8).

$T_{X X}=\frac{\cos (\emptyset)}{R_{1}}, T_{X Y}=\frac{\sin (\emptyset)}{R_{1}}, T_{Y X}=\frac{-\sin (\emptyset)}{R_{2}}, T_{Y Y}=$ $\frac{\cos (\varnothing)}{R_{2}}$

where $\varnothing$ is the counter-clockwise angle between the principal axis and the minor axis of the ellipse; $R_{1}$ is the first axis of the search ellipse and $\mathrm{R}_{2}$ refers to the second axis of the search ellipse. The $T_{X X}, T_{X Y}, T_{Y X}$, and $T_{Y Y}$ parameters are used in the calculation of $A_{X X}$, $A_{X Y}$, and $A_{Y Y}$, which are functions of the parameters in the search ellipse. These parameters are calculated using Equations (911).

$$
\begin{aligned}
& A_{X X}=T_{X X}^{2}+T_{Y X}^{2} \\
& A_{X Y}=2\left(T_{X X} T_{X Y}+T_{Y X} T_{Y Y}\right) \\
& A_{Y Y}=T_{X Y}^{2}+T_{Y Y}^{2}
\end{aligned}
$$

These values $\left(A_{X X}, A_{X Y}\right.$ and $\left.A_{Y Y}\right)$ are the same for all fulcrum points. The differences between the fulcrum $\left(X_{i}, Y_{i}\right)$ points and grid $\left(X_{0}, Y_{0}\right)$ points are then calculated as $d X$ and $d Y$.

$d X=X_{i}-X_{0}$

$d Y=Y_{i}-Y_{0}$

By means of these values, $R_{i}$ is used when calculating the weight using Equation (14).

$R_{i}=\sqrt{A_{X X} d X^{2}+A_{X Y} d X d Y+A_{Y Y} d Y^{2}}$
The $i$ in this result is used to calculate the weight of the fulcrum point $w_{i}$ using Equation (15).

$w_{i}=\left(1-R_{i}\right)^{p}, i=1 ; \ldots, N$

The $p$ value in the equation indicates the weight force that takes values between 0 and 20. Local least squares parameters are calculated with the minimized conflicting residual sum of squares using Equation (16) (Surfer 19, 2020).

$\operatorname{Minimize} \sum_{i=1}^{N} w_{i}\left[F\left(x_{i}, y_{i}\right)-z_{i}\right]^{2}$

\subsection{Weighted average (WA) Interpolation}

The basis of the method is that the weights of nearby points to be interpolated are greater than for distant points (Keçeci, 2011). The use of the WA interpolation method is highly preferred due to the simplicity of its algorithm and its easy programming. Although the method is termed simple, it gives accurate results in many applications. Surface values at interpolation points are used by calculating the weighted average of the surface values at the reference points. The same weights are not given for all dimensions because weighting is expressed by a function that depends on the distance between the interpolation point and the reference point. Less weight is given to points farther from the interpolation point, and more to points closer to the interpolation point (Kuru, 2018). In the WA method, the $N_{k}$ geoid height value corresponding to any $k$ point is found with the the $N i$ geoid height value of $n$ $(i=1,2, \ldots, n)$ for the fulcrum points by using Equations (17-19). 
$N_{k}^{\prime}=\frac{\sum_{i=1}^{n} \frac{N_{i}}{h_{i k}^{\beta}}}{\sum_{i=1}^{n} \frac{1}{h_{i k}^{\beta}}}$

$N(X, Y)=N_{\text {trend }}-N_{k}$

$h_{i k}=\sqrt{d_{i k}^{2}+\delta^{2}}$

where $\beta$ is the weight coefficient, $\delta$ is the smoothing parameter, $h_{i k}$ is the weight value based on distance, and $\mathrm{d}_{\mathrm{ik}}$ is the distance between the fulcrum and the cut-off point; $N_{\text {trend }}$ is expressed as the geoid height value determined from the fulcrum points. In this method, the weights of the fulcrums are expressed in relation to the distance. As the distance increases, the weight will decrease and approach zero, and after a specific point, it will become equal to zero. The fulcrum points with zero weight will have no effect on the estimation (Bolat, 2013). The difference between the estimated geoid height $\left(N_{i}\right)$ and the known geoid height $\left(N_{i}\right)$ of the fulcrum points is calculated using Equation (20).

$d N=N_{i}-N_{i}$

The optimal number of points and coefficient for the area studied is the coefficient that yields the lowest sum of squares for the differences between the estimated geoid height and the known geoid height of the fulcrum points (Kuru, 2018).

\subsection{Radial Basis Functions (RBFs) Interpolation}

The theory of the RBF method is based on the interpolation of functions with multiple variables. The purpose here is to interpolate the expressions shown as $\left(x^{s}, y^{s}\right)_{s=1}^{N}$. In this case, it must be $x_{s} \in R^{d}$. Since $f$ is a function in linear space in this system of equations, in the theory of $\mathrm{RBF}$, the interpolation function $f$ can be seen as a linear combination of some major functions (Topaloğlu, 2007) and is represented as an interpolation function of the RBF method, shown as:

$$
F(x, y)=\mathrm{p}(x, y)+\sum_{i=1}^{n} w_{i} . \emptyset\left(\left|(x, y)-\left(X_{i}, Y_{i}\right)\right|\right)
$$

where $p(x, y)$ represents the polynomial, wi the actual weights, $\left(\left|(x, y)-\left(X_{i}, Y_{i}\right)\right|\right)$ the Euclidean length between points, and $\varnothing(r)$ the basic function.

The application of interpolation begins with the polynomial regression step by incorporating the $p(x, y)$ polynomial. After that, the linear equation system shown in Equation (22) is solved to determine the uncertain weights.

$$
\begin{aligned}
& Z_{j}-p(x, y)=\sum_{i=1}^{n} w_{i} . \emptyset\left(\left|(x, y)-\left(X_{i}, Y_{i}\right)\right|\right), j \\
& =1, \ldots, n
\end{aligned}
$$

When the calculation of the weights is completed, the $z$ values that enable the surface to be defined are calculated for all points using Equation (21) (Solmaz, 2019). The accuracy of the MQ and IMQ methods depends on the data structure and the smoothing parameter $\left(R^{2}\right)$ specified by the user (Carlson and Foley, 1991)

\subsubsection{Multiquadric (MQ) Method}

This analytical method, first proposed by Rolland L. Hardy in 1971, is also used in solving many geodetic problems. The purpose of this interpolation technique is to define the surface via a single function created by using all known fulcrum points in the study area. The MQ method generally yields good results 
because it represents the dataset well and creates soft surfaces (Doğruluk, 2013). In order to apply the method, a trend surface is first passed through using the fulcrum points. A first- or second-degree polynomial is used as the trend surface (Tetik, 2018). Next, the residual geoid height values $\left(\Delta N_{i}\right)$ at the fulcrum points are calculated. For the MQ method, these values are used as the $\ell$ matrix; $\triangle N_{i}$ now represents the geoid height values and is calculated using Equation (23).

$$
\Delta N_{i}=N_{i}-N\left(x_{i}-y_{i}\right)=N_{i}-N_{\text {trend }}=1,2, \ldots \ldots, m
$$

If $\Delta N_{e}$ at the $\left(\mathrm{x}_{\mathrm{e}}, \mathrm{y}_{\mathrm{e}}\right)$ interpolation point is the residual geoid height value, it can be written as:

$\Delta N_{e}=N_{e}-N\left(x_{e}-y_{e}\right)=N_{e}-N_{\text {trend }}$

The values of $\Delta N_{e}$ and $N_{e}$ in this equation are unknown expressions. Finding one of these expressions allows the other to be calculated as well. Here, the geoid height values are now known as the multiquadric surface, and their coefficients can be calculated as the sum of defined second-degree equations. The multiquadric surface in its most general form is expressed by Equation (25) (Tetik, 2018).

$\Delta N=\sum_{i=1}^{n} C_{i} Q\left[x_{i}, y_{i} ; x, y\right]$

where $C_{i}$ represents the unknown coefficients calculated from the known residual height values $\Delta N_{i}$ of the fulcrum points, and $Q(x, y$, $x i, y i)$ is the kernel function.

\subsubsection{Inverse Multiquadric Function}

The generalized IMQ function was defined by Franke in 1982. The function of this method is as follows (Tetik, 2018):
$\Phi(\mathrm{r})=\frac{1}{\sqrt{r^{2}+\sigma^{2}}} \neq 0$

\section{Performance Metrics}

In order to evaluate the prediction accuracy of the methods, root mean square error (RMSE), mean absolute error (MAE), and coefficient of determination $\left(\mathrm{R}^{2}\right)$ were used.

$\operatorname{RMSE}=\left(\frac{1}{n} \sum_{i=1}^{n}\left(X_{K, i}-X_{P, i}\right)^{2}\right)^{1 / 2}$

$\operatorname{MAE}=\frac{1}{n} \sum_{i=1}^{n}\left|X_{K, i}-X_{P, i}\right|$

$\mathrm{R}^{2}=$

$\left(\sum_{i=1}^{n}\left(X_{K, i}-\bar{X}_{K}\right)\left(X_{P, i}-\bar{X}_{P}\right) / \sqrt{\sum_{i=1}^{n}\left(X_{K, i}-\bar{X}_{P}\right)^{2} \sum_{i=1}^{n}\left(X_{P, i}-\bar{X}_{P}\right)^{2}}\right)^{2}$

In Equations (27), (28), and (29), $n$ indicates the number of data, $X_{K, i}$ and $X_{P, i}$ are the known and predicted values, respectively, and $\bar{X}_{K}$ and $\bar{X}_{P}$, represent the mean values of the known and predicted values, respectively. The RMSE and MAE range from 0 to $+\infty$, while the range for $\mathrm{R}^{2}$ is from 0 to 1 . Low RMSE and MAE values and high $\mathrm{R}^{2}$ indicate that the developed model is good.

\section{Results and Discussion}

The spread parameter that affects the accuracy of the GRNN prediction results should be suitably determined. The trial-and-error procedure was used to determine the optimum spread parameter. The power parameter $(k)$ is an important factor in the WA method. In the study, $k$ values between 1 and 5, respectively, were tried, the amount of error was observed, and five different results were obtained. For RBF modeling, MQ and IMQ functions were used. In order to prepare models using the LP function, 1, 5, 10, 15, and 20 were used as the 
polynomial function degrees, respectively. The statistical values used to evaluate the performance of these methods are shown in Table 2.

In order to determine the prediction accuracy of the five methods as a performance criterion, the minimum absolute difference, maximum
RMSE $=1.215 \mathrm{~cm}, \mathrm{MAE}=0.467 \mathrm{~cm}$, and $\mathrm{R}^{2}$ $=0.99980$. The worst result was found with the model created by choosing the power parameter of $1(p=1)(\mathrm{RMSE}=14.160 \mathrm{~cm}$, MAE $\left.=11.237 \mathrm{~cm}, \mathrm{R}^{2}=0.97308\right)$. As shown in Table 2, the maximum absolute difference $(57.375 \mathrm{~cm})$ was obtained with the LP function and the minimum absolute difference

Table 2. Performance statistics for GRNN, WA, MQ, IMQ, and LP methods

\begin{tabular}{ccccccc}
\hline Method & $\begin{array}{c}\text { Minimum } \\
(\mathrm{cm})\end{array}$ & $\begin{array}{c}\text { Mean } \\
(\mathrm{cm})\end{array}$ & $\begin{array}{c}\text { Maximum } \\
(\mathrm{cm})\end{array}$ & $\begin{array}{c}\text { RMSE } \\
(\mathrm{cm})\end{array}$ & $\begin{array}{c}\text { MAE } \\
(\mathrm{cm})\end{array}$ & $\mathrm{R}^{2}$ \\
\hline GRNN & 0.000 & 0.445 & 6.992 & 1.215 & 0.467 & 0.99980 \\
WA $(k=1)$ & 0.040 & 8.792 & 35.644 & 11.257 & 9.229 & 0.98339 \\
WA $(k=2)$ & 0.003 & 5.284 & 19.467 & 6.888 & 5.547 & 0.99359 \\
WA $(k=3)$ & 0.069 & 4.461 & 24.274 & 6.034 & 4.871 & 0.99532 \\
WA $(k=4)$ & 0.043 & 4.780 & 21.286 & 6.166 & 5.018 & 0.99532 \\
WA $(k=5)$ & 0.016 & 3.568 & 17.162 & 5.063 & 3.745 & 0.99508 \\
MQ & 0.007 & 4.081 & 64.594 & 7.175 & 4.284 & 0.99361 \\
IMQ & 0.007 & 3.624 & 19.001 & 5.175 & 3.807 & 0.99611 \\
LP $(p=1)$ & 0.001 & 10.705 & 57.375 & 14.160 & 11.237 & 0.97308 \\
LP $(p=5)$ & 0.061 & 7.485 & 34.554 & 9.833 & 7.857 & 0.98704 \\
LP $(p=10)$ & 0.018 & 5.532 & 23.241 & 7.371 & 5.807 & 0.99282 \\
LP $(p=15)$ & 0.030 & 4.676 & 31.807 & 6.472 & 4.909 & 0.99454 \\
LP $(p=20)$ & 0.148 & 22.703 & 84.363 & 6.117 & 4.448 & 0.99515 \\
\hline
\end{tabular}

absolute difference, mean absolute difference, RMSE, MAE, and $\mathrm{R}^{2}$ were calculated. Table 2 shows that the best result was obtained with the power parameter of $5(k=5)$ among the WA methods. On the other hand, the worst result was determined for the model in which the power parameter was chosen as $1(k=1)$. The LP functions model created with a power parameter of $20(p=20)$ yielded the best result within itself. The worst result was found to be in the model developed by choosing the power parameter of $1(p=1)$. The MQ and IMQ methods gave results similar to the WA method $(k=1,2,3,4,5)$. When the results were evaluated overall, the statistical indices for the GRNN showed the lowest RMSE and MAE and the highest $\mathrm{R}^{2}$; values equal to:
$(4.08 \mathrm{E}-09 \mathrm{~cm})$ with the GRNN method. In addition, the mean absolute difference $(0.445$ $\mathrm{cm})$ was obtained using the GRNN method. Moreover, the distribution diagrams of geoid undulations estimated against known geoid undulation values are given in Figure 4 for the WA method, in Figure 5 for the LP function, and in Figure 6 for the GRNN, IMQ, and MQ methods. 

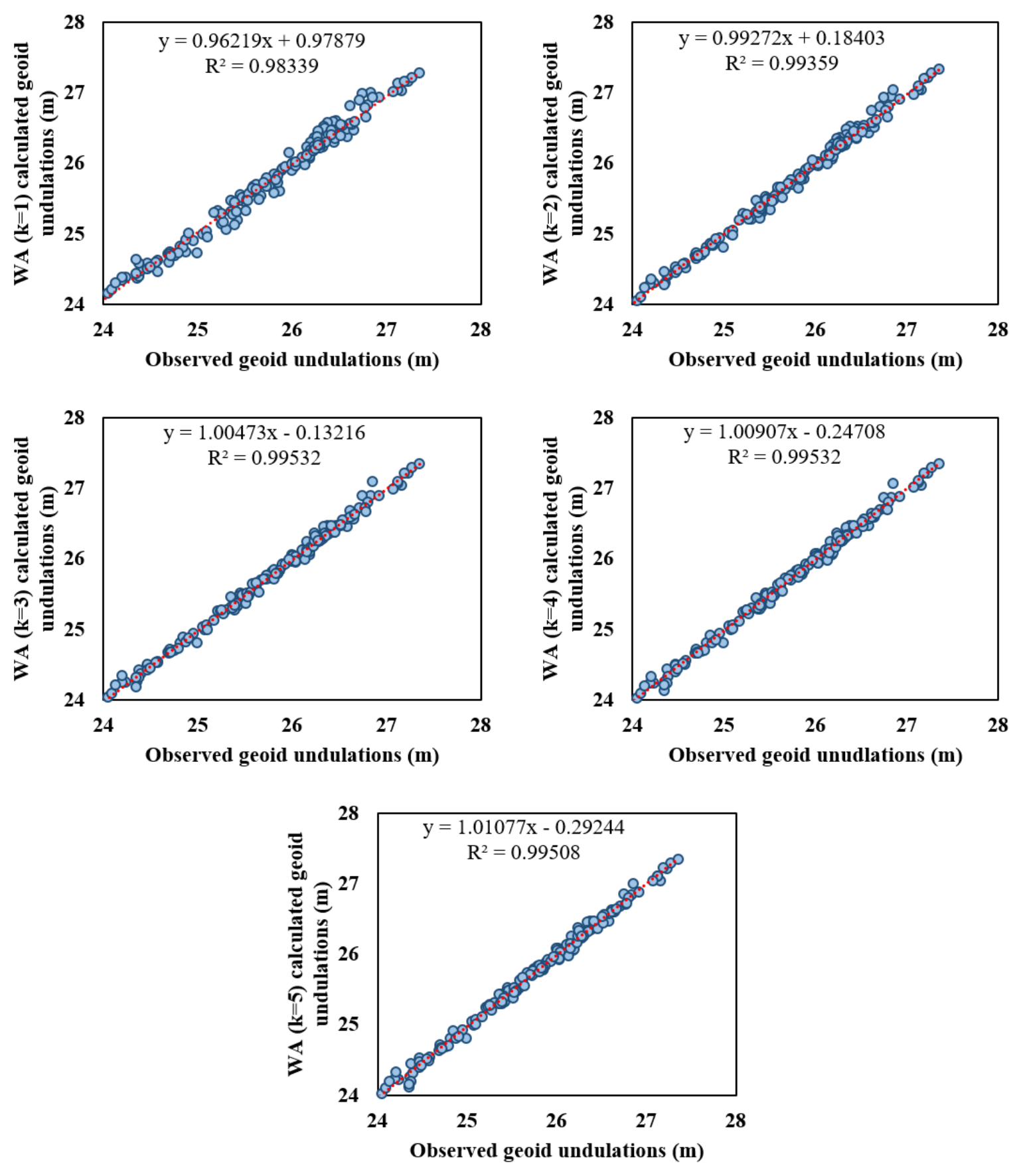

Figure 4. Scatter diagrams of known geoid undulation values estimated by weighted average $(k=1,2,3,4,5)$ 

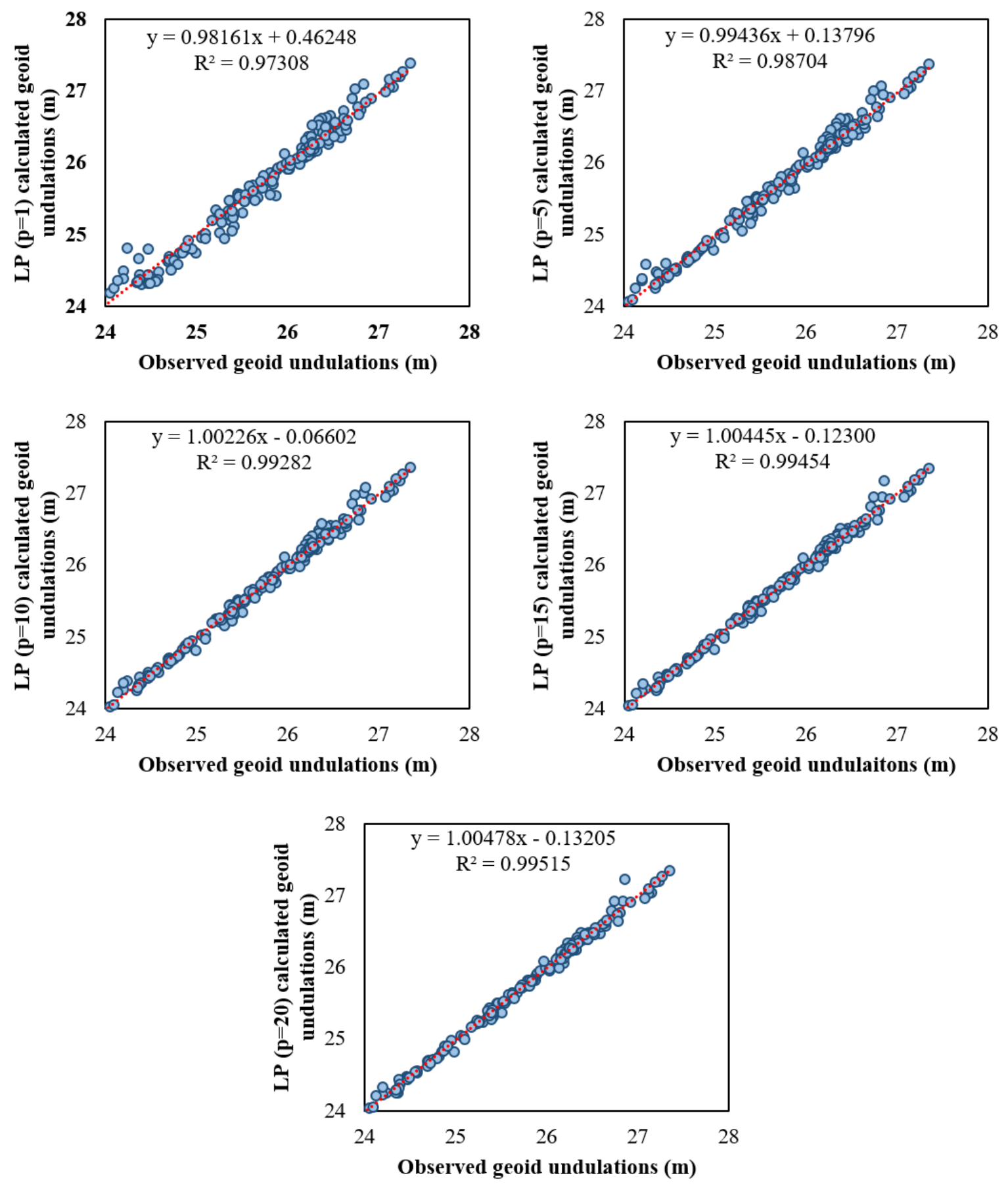

Figure 5. Scatter diagrams of known geoid undulation values estimated by local polynomial ( $p$ $=1,5,10,20$ ) 

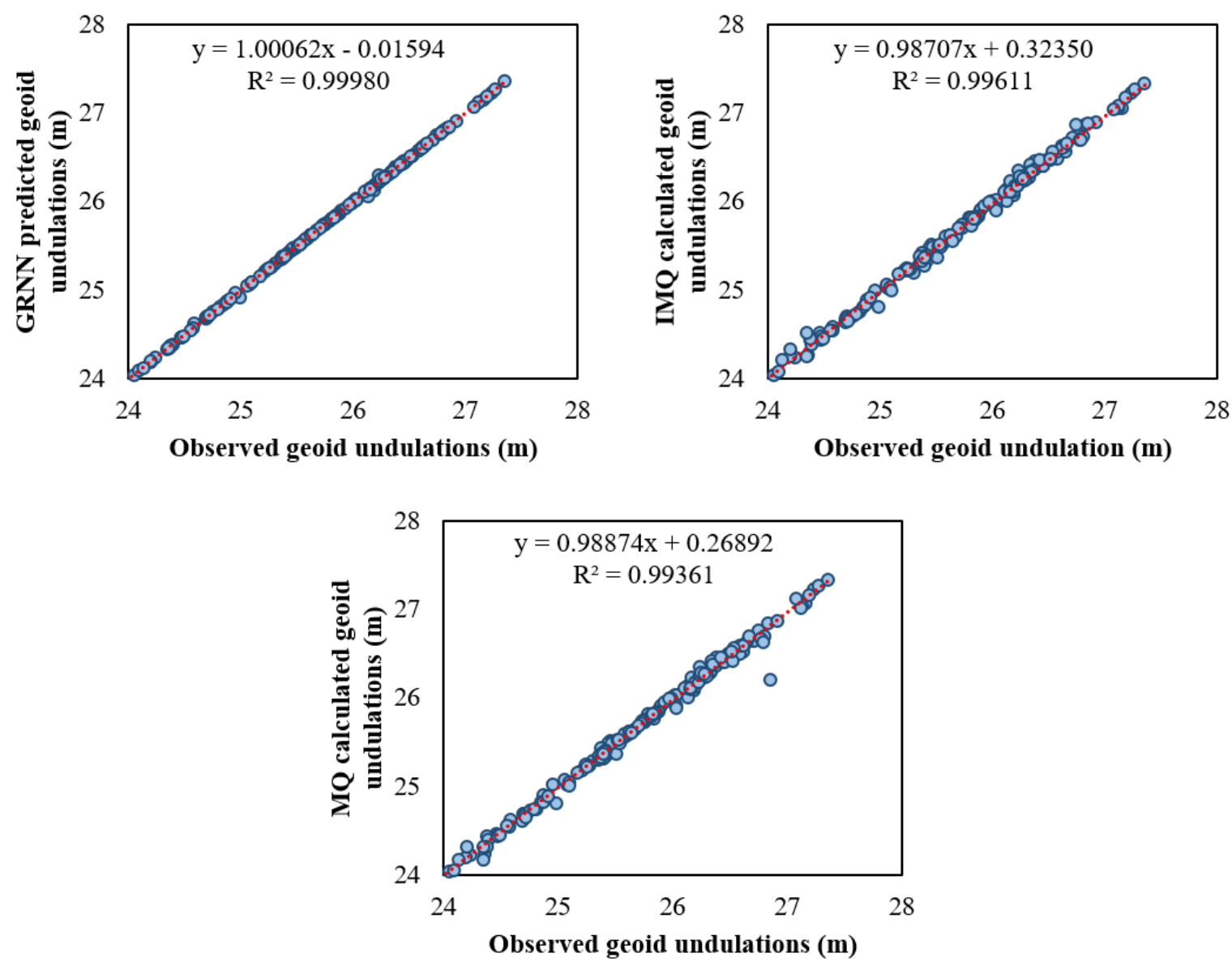

Figure 6. Scatter diagrams of known geoid undulation values estimated by GRNN, IMQ, and MQ methods

From these Figures, it can be observed that prediction using GRNN show more scatter around the line of perfect agreement in comparison to other methods. Also, as seen from the fit line equations the slope and bias values of the GRNN are closer the 1 and 0 than the WA, LP, IMQ, and MQ methods.

\section{Conclusions}

The purpose of this study was to determine a local geoid using the generalized regression artificial neural network (GRNN), weighted average (WA), multiquadric (MQ) and inverse multiquadric (IMQ), radial basis functions (RBF), and local polynomial (LP) methods and to compare the results. For this purpose, 473 GNSS/leveling points were chosen as reference points and 169 GNSS/leveling points as test points. The same datasets were used for all methods. According to the results obtained, the GRNN, with the highest $\mathrm{R}^{2}$ (0.99980) and the lowest RMSE $(1.215 \mathrm{~cm})$ and MAE $(0.467 \mathrm{~cm})$, showed superiority over the other methods. The WA methods gave similar results among themselves, except for the model with a power parameter of $1(k=1)$. The MQ and IMQ methods also gave results similar to those of the WA method. Performance results of the LP functions were less accurate than those of the other methods. The accuracy achieved in this work is sufficient for many geodetic and surveying applications. The GRNN offers advantages over the back propagation neural network such as a single-pass learning 
algorithm, fast generalization, and a flexible and high-tolerance network architecture. After evaluating the study results, the authors believe the GRNN to be worth considering in the modeling of a variety of geodesy problems.

\section{Acknowledgement}

The authors of this article thank the Erzincan XXIV Regional Directorate of Land Registry and Cadastre for providing the data used in the study.

\section{References}

Albayrak, M., Özlüdemir, M. T., Aref, M. M., Halicioglu, K. 2020. "Determination of Istanbul geoid using GNSS/levelling and valley cross levelling data", Geodesy and Geodynamics, 11(3), 163-173.

Becker, M. 2012. "Geodesy”, Springer handbook of geographic information, Springer, Springer Heidelberg Dordrecht London New York, 185-208.

Bolat, S. 2013 "Lokal Jeoid Belirleme Yöntemleri: Samsun İli Örneği”, Yüksek Lisans Tezi, Ondokuz Mayıs Üniversitesi Fen Bilimleri Enstitüsü, Samsun, 30-32.

Cakir, L. and Yilmaz, N. 2014. "Polynomials, radial basis functions and multilayer perceptron neural network methods in local geoid determination with GPS/levelling", Measurement, 57, 148-153.

Carlson, R.E. and Foley, T.A. 1991. "The Parameter $\mathrm{R}^{2}$ in Multiquadric Interpolation", Computers \& Mathematics with Applications, 21, 29-42.

Ceylan, A., Üstün, A., Doğanalp, S., Gürses, H.B. 2011. "Karayolu ve Demiryolu
Projelerinde Ortometrik Yükseklik Hesabı: En küçük Kareler ile Kollokasyon", 13. Türkiye Harita Bilimsel ve Teknik Kurultayl, TMMOB Harita ve Kadastro Mühendisleri Odası, Ankara, 1-8.

Doganalp, S. 2016. "Geoid height computation in strip-area project by using least-squares collocation", Acta Geodyn. Geomater, 13(2), 182.

Doganalp, S. and Selvi, H.Z. 2015. "Local geoid determination in strip area projects by using polynomials, least-squares collocation and radial basis functions", Measurement, 73, 429-438.

Doğruluk, M. 2013 "Sayısal arazi modellerinin karayolu projelerindeki hacim hesaplamalarına etkisi”, Doktora Tezi, Selçuk Üniversitesi Fen Bilimleri Enstitüsü, Konya, 43-45.

Erol, S. and Erol, B. 2020. "A comparative assessment of different interpolation algorithms for prediction of GNSS/levelling geoid surface using scattered control data", Measurement, in press.

Featherstone, W.E., Dentith, M.C., Kirbiy, J.F. 1998. "Strategies for accurate determination of orthometric heights from GPS”, Survey Review, 34(267), 278-296.

Fidanc1, Y. and Abbak, R. A. 2019. "Yerel Jeoit Belirlemede Yapay Sinir Ağlarının Farkl1 Nokta Yoğunluğundaki Performans1", Gümüşhane Üniversitesi Fen Bilimleri Enstitüsü Dergisi, 9(3), 486-495.

Güllü, M., Turgut, B., Baybura, T. 2016. "Jeoid Yüksekliklerinin Belirlenmesinde Yapay Sinir Ağları ve Kriging Enterpolasyon Yöntemlerinin Karşılaştırılması“", Afyon 
Kocatepe Üniversitesi Fen ve Mühendislik Bilimleri Dergisi, 16(3), 674-678.

İnal, C., Turgut, B., Yiğit, C.Ö. 2002. "Lokal Alanlarda Jeoit Ondülasyonlarının Belirlenmesinde Kullanilan Enterpolasyon Yöntemlerinin Karşılaştırılması”, Selçuk Üniversitesi Jeodezi ve Fotogrametri Mühendisliği Öğretiminde 30. Yll Seтроzуити, Selçuk Üniversitesi, Konya, 97 106.

Kaloop, M. R., Rabah, M., Hu, J. W., Zaki, A. 2018. "Using advanced soft computing techniques for regional shoreline geoid model estimation and evaluation", Marine Georesources and Geotechnology,36(6), 688-697.

Karaaslan, Ö., Kayıkçı, E. T., Aşık, Y. 2016. "Comparison of local geoid height surfaces, in the province of Trabzon", Arabian Journal of Geosciences, 9(6), 431.

Kavzoglu, T. and Saka, M.H. 2005. "Modelling local GPS/levelling geoid undulations using artificial neural networks", Journal of Geodesy, 78, 520-27.

Keçeci, S.B. 2011 "Sayısal Yükseklik Modellerinin Oluşturulmasında Kullanılan Enterpolasyon Yöntemlerinin Karşılaştırılması”. Yüksek Lisans Tezi, Ondokuz Mayıs Üniversitesi Fen Bilimleri Enstitüsü, 37-38.

Kuru, B. 2018 "Lokal Jeoid Belirlemede Kullanılan Enterpolasyon Yöntemlerinin Karşılaştırılması”, Yüksek Lisans Tezi, Afyon Kocatepe Üniversitesi Fen Bilimleri Enstitüsü, Afyon, 25-28.

Seager, J., Collier, P., Kirby, J. 1999. "Modelling Geoid Undulations with an Artificial Neural Network", IEEE
International Joint Conference on Neural Networks, Washington, DC, USA, 33323335.

Solmaz, M. 2019 "Gnss/Nivelman Verisi İle Yerel Jeoid Profilinin Farklı Enterpolasyon Yöntemleriyle Çıkarılması", Yüksek Lisans Tezi, Afyon Kocatepe Üniversitesi Fen Bilimleri Enstitüsü, Afyon, 52-57.

Specht, D. F. 1991. “A General Regression Neural Network", IEEE Transactions on Neural Networks, 2(6), 568-576.

Şişman, Y. and Elevli, B. 2018. "En Küçük Kareler Kollokasyon ve Kriging Yöntemleri ile Lokal Jeoid Belirleme“, Karadeniz Fen Bilimleri Dergisi, 8(2), 106-118.

Surfer 19, 2020. Surfer 19 User's Guide, Golden Software, Inc. Colorado, USA.

Tetik, K. 2018 "Farkl1 Enterpolasyon Teknikleri Kullanılarak Yerel Jeoit Belirleme", Yüksek Lisans Tezi, Necmettin Erbakan Üniversitesi Fen Bilimleri Enstitüsü, Konya, 18-20.

Topaloğlu, V. 2007 "Yapay Sinir Ağları ile Dalga Yüksekliği Tahmini”, Yüksek Lisans Tezi, İstanbul Teknik Üniversitesi Fen Bilimleri Enstitüsü, İstanbul, 17-19.

Üstün, A. 2001. “GPS Nivelmanı Yardımıyla Ortometrik Yüksekliklerin Elde Edilmesine Yönelik Jeoit Belirleme Yöntemleri”, YTÜ Dergisi, 1, 62-82.

Yanalak, M. and Baykal, O. 2001. "Transformation of ellipsoid heights to local leveling heights", Journal of Surveying Engineering, 127(3), 90-103.

Y1lmaz, M. and Kuru, B. 2019. "Makro ve Mikro Ölçekteki Lokal Jeoid Tespiti için 
Enterpolasyon Yöntemlerinin

Karş1laştırılması", Geomatik, 4(1), 41-48.

Y1lmaz, N. 2019. "Jeoid yüksekliklerinin belirlenmesinde ağırlıklı ortalama ve polinomlarla enterpolasyon yöntemlerinin karşılaştırılması", Dicle Üniversitesi Mühendislik Fakültesi Mühendislik Dergisi, 10(2), 743-754.

Zhan-ji, Y. and Yong-qi, C. 1999. "Determination of local geoid with geometric method: Case study", Journal of Surveying Engineering, 125(3), 136-146. 